\title{
The fish community in Gulf of Mexico mangroves, a response to hydrological restoration
}

\author{
Miriam Soria-Barreto ${ }^{1}\left(\mathbb{D}\right.$, Rolando Gelabert Fernández ${ }^{1}$ \\ Hiram Eduardo Reyna Ramos ${ }^{1}$ (D) \& Roberto Brito ${ }^{1}$ (i) \\ ${ }^{1}$ Centro de Investigación de Ciencias Ambientales, Facultad de Ciencias Naturales \\ Universidad Autónoma del Carmen, Campeche, México \\ Corresponding author: Miriam Soria-Barreto (mmsoriab@gmail.com)
}

\begin{abstract}
The present study evaluated the ecological response of fish fauna to hydrological restoration in a mangrove area in Terminos Lagoon in the Gulf of Mexico. In two years, environmental parameters and ichthyofauna were obtained in a channel under restoration and a conserved channel. The fish fauna was composed of 12 species. As a result of the restoration process, changes in composition and abundance of some species were detected. The presence of visiting marine species Bathygobius soporator and Eucinostomus melanopterus, and an increase in the abundance of resident fish, livebearers species, were recorded. Richness, diversity, and evenness vary significantly between channels. Generalized linear mixed models indicated that the abundances of resident and overall fishes were significantly related to water depth, temperature, and salinity. The results suggest that fish are an ecological indicator of the mangrove reconnection with the Terminos Lagoon and the restoration of natural tidal flow in the short term. Long-term systematic monitoring of fish fauna will promote a better understanding of the restoration of mangroves and corresponding changes in the function of this ecosystem.
\end{abstract}

Keywords: tropical mangrove; resident species; visiting species; composition; Terminos Lagoon; Gulf of Mexico

\section{INTRODUCTION}

Mangrove forests are coastal ecosystems with high productivity and biological diversity. They play a critical role for wildlife, providing resources for the development and establishment of numerous species (Nagelkerken et al. 2008) and forming an important habitat for juvenile reef fishes and commercially important species (Blaber 2007). Furthermore, mangroves provide environmental services, including nutrient regulation, water supply, and coastal protection (Himes-Cornell et al. 2018). Despite the importance of mangrove forests, about $50 \%$ of their surface has disappeared worldwide (Romañach et al. 2018). The main factors responsible for the disappearance of mangrove forests are natural factors like hurricanes or tsunamis and changes in land use produced by human settlements, livestock activity, aquaculture, and deforestation. Faced with this loss, several organizations, governments, and social sectors have developed and promoted mangrove conservation and restoration (López-Portillo et al. 2017). For example, in Mexico, actions include protecting natural areas, reforestation, and restoration (Zaldívar-Jiménez et al. 2010, CONABIO \& SEMARNATCAM 2016).

Restoration projects in mangrove ecosystems have focused mainly on improving ecological conditions. Some reforestation projects used select species intending to support timber production (Ellison 2000). Lately, the purpose is to promote biological and shoreline conservation, increase fisheries and eventually restore ecosystem function (Bosire et al. 2008, López-Portillo et al. 2017). A recent alternative is a hydrological restoration, which involves dredging and

Corresponding editor: Yassir Torres 
rehabilitation of tidal channels, aiming to restore the natural tide flow to reconstruct the structural characteristics of the ecosystem, such as improving soil and water conditions and promoting natural regeneration of mangrove. Hydrological restoration is considered a relevant factor for the health of the mangrove and the ecosystem as a whole (Turner \& Lewis III 1997, Moreno-Mateos et al. 2012, Echeverría-Ávila et al. 2019, Pérez-Ceballos et al. 2020).

The success of restoration projects is evaluated by different ecological indicators (Wortley et al. 2013). For example, in mangrove ecosystems, the mangrove structure, abundance, and diversity of associated fauna are recognized (Ellison 2000, Bosire et al. 2008, Zhao et al. 2016). Species diversity, ecological functions, and environmental services are expected to be restored similarly to natural ecosystems, so it is essential to monitor the progress of ecological restorations over time (Gilman et al. 2008, Moreno-Mateos et al. 2020).

It is important to assess the response of fish fauna to restoration because they are the most diverse and abundant nektonic organisms associated with mangroves (Blaber 2007, Nagelkerken et al. 2008). Many fish species have a life-cycle dependent on mangrove forests: juveniles use it as a nursery site protected from predators, and both adults and juveniles use it to acquire various food resources (Lee et al. 2014, Whitfield 2017). Several attributes of ichthyofauna have been evaluated through the mangrove restoration processes, including richness, biomass, composition, and diversity (Lewis III \& Gilmore 2007, Salmo III et al. 2018). For example, fish fauna in restored areas showed an increase of abundance and species richness over time (Arceo-Carranza et al. 2016), increase of richness and secondary production of resident species (Valentine-Rose \& Layman 2011), increase of diversity and evenness (Adite et al. 2013), and the entrance of transient species (Schaberg et al. 2019).

Terminos Lagoon is an important coastal ecosystem located in the southern Gulf of Mexico, established as a Natural Protected Area of Flora and Fauna, and recognized for its biodiversity and abundance of mangrove forests (Herrera-Silveira et al. 2019). The fish community associated with mangroves is diverse. The majority are marine species that enter the lagoon cyclically or sporadically, in addition to estuarine and freshwater species that can live in euryhaline conditions (Yáñez-Arancibia et al. 1993). Recent studies indicate that fish diversity in mangrove habitats is composed of 18 (Amador-del Ángel et al. 2015) up to 34 species, in the area of mangrove and seagrass (Sepúlveda-Lozada et al. 2017). However, this ecosystem is under threat due to anthropogenic activities and natural phenomena (Soto-Galera et al. 2010, Zaldívar-Jiménez et al. 2017).

Hydrological restoration projects for the mangrove ecosystem have resulted in recruitment and mangrove growth, hydrological reconnection with Terminos Lagoon, and lower-salinity soils (Zaldívar-Jiménez et al. 2017, Pérez-Ceballos et al. 2020). As for wildlife, bird communities were more diverse in the restored $v s$. natural sites (Canales-Delgadillo et al. 2019), while ectoparasites of Yucatan gambusia Gambusia yucatana did not differ in diversity between restored $v s$. natural sites (Morales-Serna et al. 2019). Although fish are a very diverse taxonomic group in this ecosystem with a life cycle closely related to the mangrove (Amador-del Ángel et al. 2015, Sepúlveda-Lozada et al. 2017), the response of the fish community to the restoration process has not been evaluated in Terminos Lagoon.

This study aimed to evaluate the richness, diversity, composition, and abundance of resident fish and visiting fish in a channel under restoration contrasted with a conserved channel within the mangrove zone of Terminos Lagoon in the Gulf of Mexico. We predicted that the environmental conditions of the channel under restoration would improve as a result of hydrological restoration. We expected that the fish community would increase the species richness and abundance of visiting marine fishes entering the mangrove (Lewis III \& Gilmore 2007). Also, we expected that resident species showed a change in abundance in response to restoration because they spend their entire life cycles in mangroves (Vose \& Bell 1994, Arceo-Carranza et al. 2016).

\section{MATERIALS AND METHODS}

The study was carried out in Bahamitas Estuary, located on the inner coast of Carmen Island in Terminos Lagoon (Campeche, Mexico). This area has constant marine influence due to circulation patterns, and the tides are diurnal mixed astronomical with an amplitude of $0.43 \mathrm{~m}$ (Escudero et al. 2014). There are three climatic seasons in the year: dry season (March to May), rainy season (June to September), and "nortes season" (winter fronts) (October to February) (HerreraSilveira et al. 2019).

Two channels of mangrove with different degrees of conservation were selected for this study. The "conserved channel" $\left(18^{\circ} 41^{\prime} 5.5^{\prime \prime} \mathrm{N}, 91^{\circ} 39^{\prime} 36.9^{\prime \prime} \mathrm{W}\right)$ is a natural channel permanently connected to the lagoon, with a preserved mangrove composed of red mangrove Rhizophora mangle on the margins and black mangrove Avicennia germinans inland. The "channel under restoration" $\left(18^{\circ} 41^{\prime} 22.6^{\prime \prime} \mathrm{N}, 91^{\circ} 38^{\prime} 6.5^{\prime \prime} \mathrm{W}\right)$ is a degraded channel that underwent hydrological restoration in late 2015. This channel comprises dead mangrove which 


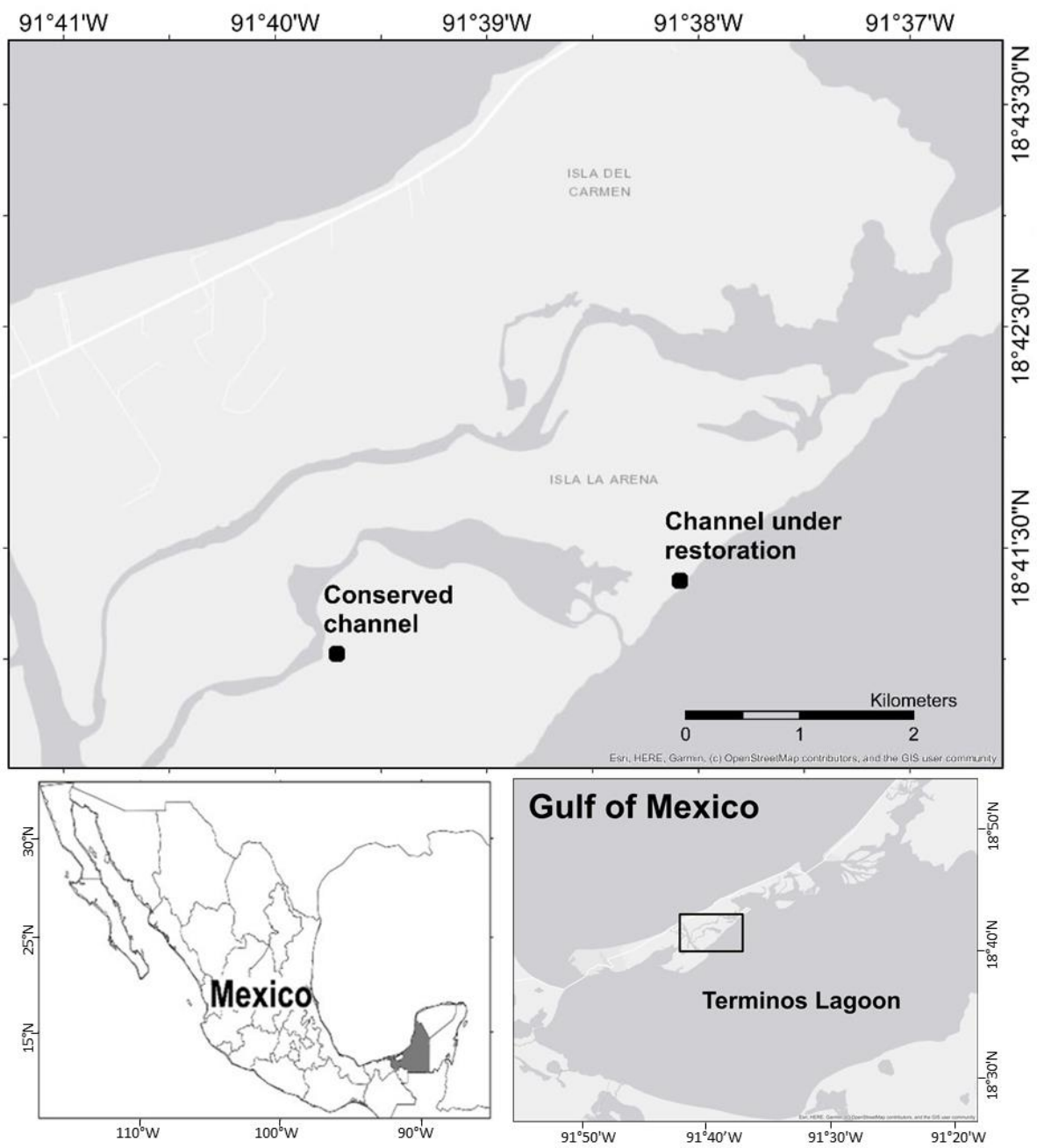

Figure 1. Location of the sampling channels in Terminos Lagoon, Mexico.

lost connectivity with the Terminos Lagoon due to damage sustained after Hurricane Roxana and Hurricane Opal in 1995 (Zaldívar-Jiménez et al. 2017) (Fig. 1).

Five sampling sites were located at each channel, 20 $\mathrm{m}$ apart from each other. The sampling was performed in the same sites in February, June, and September to cover the climatic seasons during 2015 and 2017. Before sampling at each site, the water depth was measured using a measuring stick. Temperature, salinity, conductivity, and $\mathrm{pH}$ were obtained with a YSI 63 multiparametric water quality instrument.

Fishes specimens were collected using baited minnow traps and baited fish traps. Two minnow traps $(42.7 \mathrm{~cm}$ long $\times 25.5 \mathrm{~cm}$ wide $\times 25.5 \mathrm{~cm}$ high; $2 \mathrm{~cm}$ mesh) were placed in channel margins in each site. Also, two fish traps (cylindric traps of $60 \mathrm{~cm}$ long $\times 26$ $\mathrm{cm}$ diameter; $1 \mathrm{~cm}$ mesh) were placed in the middle of the channel. During the low tide in all months and years, the sampling was done for two hours in the morning for two days. These techniques were selected after used seine nets $(7.7 \mathrm{~m}$ long and $1 \mathrm{~cm}$ mesh; 10.8 $\mathrm{m}$ and $2 \mathrm{~cm}$ mesh; 5 replicates per site) and Fyke traps ( $2.5 \mathrm{~m}$ long and $0.5 \mathrm{~mm}$ mesh; $5 \mathrm{~h}$ per site) without effectiveness in sampling.

All the fishes caught were placed on ice; in the laboratory, they were preserved in $70 \%$ ethyl alcohol and identified according to specialized taxonomic keys (Castro-Aguirre et al. 1999, Carpenter 2002, Miller 2009). Each specimen's weight (g) and standard length (mm) were measured using an Ohaus balance (with a precision of $0.01 \mathrm{~g}$ ) and electronic caliper (with a precision of $0.01 \mathrm{~mm}$ ), respectively.

The relative abundance of species (RA) was calculated; it is the percentage of individuals divided by the total individuals. The frequency of occurrence (FO) was calculated as the percentage of the number of samplings with the species appearance divided by the 
total number of samplings. The fish residency in mangroves was obtained based on the frequency of occurrence (Padilla-Serrato et al. 2017). Resident species (100-61\% FO) that reproduce feed and grow within mangroves. The seasonal visitor (60-31\% FO), the species depend on the mangrove at some stage of their life cycle. Occasional visitor species (30-0\% FO) that use the mangrove without a regular pattern.

Environmental variables were transformed into logarithms for analysis to comply with the assumptions of normality and homoscedasticity. The characteristics of the environment between the channels, seasons, and the years were compared, using a non-metric multidimensional scaling (NMDS) with the Euclidean distance index (Clarke 1993). A PERMANOVA was performed with the Euclidean distance index and 10,000 permutations to identify environmental differences between channels, seasons, years, and interactions (Anderson 2001).

An analysis of similarity (ANOSIM, Clarke \& Warwirck 1998) was performed to compare the fish composition of channels, using the Bray-Curtis index, 9999 permutations, and the abundance fish transformed into logarithm $(\mathrm{x}+1)$. Post-hoc analysis allowed identifying between which pairs there were significant differences. A similarity percentage analysis (SIMPER, Clarke \& Warwirck 1998) was used to identify which species contributed to differences when there was a significant difference.

Richness (number of species), the Shannon diversity index $(\mathrm{H})$, and the Pielou evenness $(\mathrm{J})$ were calculated for each channel in each season and year. Species abundance was calculated for visiting and resident fish. These descriptors were transformed into logarithm $(x+1)$ and compared between channels, season, and years using a PERMANOVA analysis with 10,000 permutations and Euclidian distance index.

Community descriptors and multivariate analyses were obtained using the vegan package (Oksanen et al. 2019 ) in version 3.6.3 of the R statistical software ( $R$ Core Team 2000).

Spearman correlation test of environmental variables was performed to eliminate the redundant variables with large significant correlation. A generalized linear mixed model (GLMM) was used to evaluate the influence of the different variables in the community, using the environmental parameters as simple effects and the community descriptors as the dependent variable. This analysis was performed using the lme 4 package in $\mathrm{R}$ (Bates et al. 2015). According to the Akaike Information Criterion (AIC) and the Bayesian Information Criterion (BIC), the best model was selected.

\section{RESULTS}

\section{Environmental analysis}

The NMDS plot shows the separation between channel sites under restoration $v s$. conserved sites $(\mathrm{R}=0.035)$ (Fig. 2). Grouping is observed according to the degree of conservation and the year of sampling due to environmental differences.

The water depth was greater at the conserved sites (Table 1). There was a significant difference between channels, years, seasons, and the interaction between channels and years (Table 2). The channel under restoration had a higher temperature in 2015 (Table 1). There were significant differences between channels, years, seasons, the interaction between channels and years, channels and seasons, years and seasons, and channels, years and seasons (Table 2).

The salinity was greater in 2017 (Table 1); it varied significantly between years, seasons, and the interaction between years and seasons (Table 2). The conductivity was greater in channel sites under restoration (Table 1). There was a significant difference between channels, seasons, the interaction between channel and seasons, years and seasons, and channels, years and seasons (Table 2). The $\mathrm{pH}$ varied between years, seasons, the interaction between channel and seasons, years and seasons, and channels, years and seasons (Table 2).

\section{Fish fauna analysis}

A total of 2824 organisms were collected, representing 12 species, seven families, and four orders.

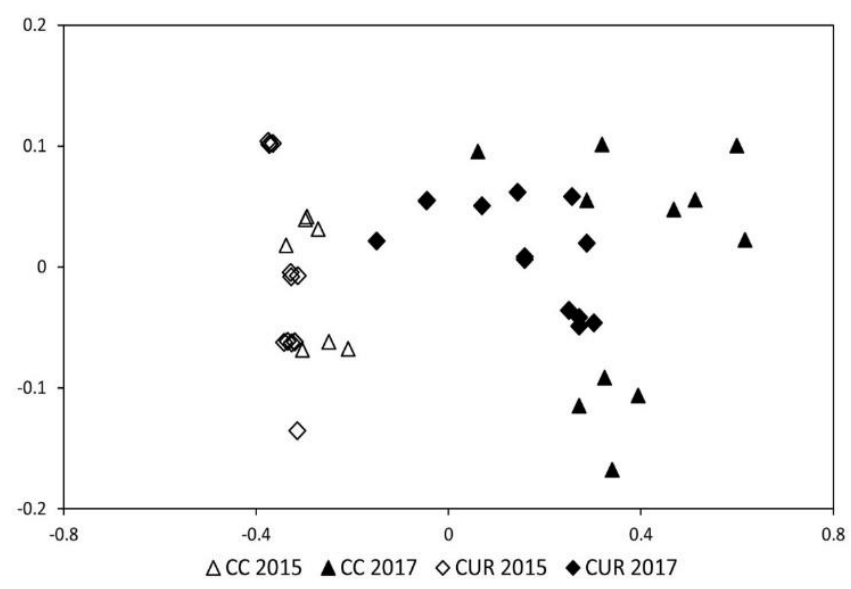

Figure 2. Non-metric multidimensional scaling (NMDS) of the environmental characteristics of sites of the conserved channel (CC) and channel under restoration (CUR) in Terminos Lagoon in 2015 and 2017. Stress $=0.035$. 
Table 1. Environmental characteristics of conserved channel and channel under restoration in Terminos Lagoon. Mean values and the standard deviation (in parenthesis) are included.

\begin{tabular}{lllccccc}
\hline Year & Channel & Season & $\begin{array}{c}\text { Water depth } \\
(\mathrm{m})\end{array}$ & $\begin{array}{c}\text { Temperature } \\
\left({ }^{\circ} \mathrm{C}\right)\end{array}$ & Salinity & $\begin{array}{c}\text { Conductivity } \\
\left(\mathrm{s} \mathrm{cm}^{-1}\right)\end{array}$ & $\mathrm{pH}$ \\
\hline 2015 & Conserved & Nortes & $1.3(0.1)$ & $24.5(0.1)$ & $30.9(0.0)$ & $47.4(0.1)$ & $8.2(0.0)$ \\
& & Dry & $1.7(0.1)$ & $29.5(0.0)$ & $31.5(0.8)$ & $50.3(5.3)$ & $9.1(0.0)$ \\
& & Rainy & $1.5(0.1)$ & $31.7(0.1)$ & $35.8(0.2)$ & $54.1(0.1)$ & $6.7(0.0)$ \\
& \multirow{4}{*}{ Under restauration } & Nortes & $0.4(0.0)$ & $22.3(0.1)$ & $33.0(0.1)$ & $50.4(0.0)$ & $7.7(0.4)$ \\
& & Dry & $0.4(0.2)$ & $35.6(0.6)$ & $37.1(2.9)$ & $56.9(8.0)$ & $9.0(0.1)$ \\
2017 & \multirow{5}{*}{ Conserved } & Rainy & $0.3(0.1)$ & $36.7(0.4)$ & $35.2(0.7)$ & $52.0(5.5)$ & $6.8(0.3)$ \\
& & Nortes & $1.6(0.0)$ & $25.4(0.1)$ & $38.9(0.0)$ & $45.7(5.2)$ & $7.9(0.0)$ \\
& & Dry & $1.9(0.0)$ & $31.5(0.0)$ & $42.9(0.0)$ & $63.8(0.0)$ & $8.2(0.0)$ \\
& \multirow{2}{*}{ Under restauration } & Rainy & $1.7(0.0)$ & $31.2(0.0)$ & $30.1(0.0)$ & $46.6(0.0)$ & $8.5(0.0)$ \\
& & Nortes & $0.7(0.3)$ & $27.5(0.4)$ & $37.3(0.1)$ & $56.2(0.1)$ & $8.0(0.0)$ \\
& & Dry & $0.7(0.2)$ & $30.9(0.4)$ & $39.8(0.2)$ & $59.7(0.2)$ & $8.5(0.1)$ \\
& & Rainy & $0.4(0.0)$ & $31.1(0.0)$ & $30.4(0.3)$ & $46.7(0.0)$ & $8.4(0.2)$ \\
\hline
\end{tabular}

Table 2. Results of PERMANOVA testing the differences of environmental parameters between channels, years, seasons, and their interactions. df: degres of freedom, MS: mean sum of squares, F: pseudo-F statistics value, $P: P$-value.

\begin{tabular}{|c|c|c|c|c|c|c|c|c|c|}
\hline Water depth factor & $\mathrm{df}$ & MS & $\mathrm{F}$ & $P$ & Temperature factor & df & MS & $\mathrm{F}$ & $P$ \\
\hline Channel & 1 & 3.58 & 308.52 & $<0.001$ & Channel & 1 & 0.01 & 588.77 & $<0.001$ \\
\hline Year & 1 & 0.24 & 20.76 & $<0.001$ & Year & 1 & 0 & 274.92 & $<0.001$ \\
\hline Season & 2 & 0.04 & 3.6 & 0.044 & Season & 2 & 0.05 & 2618.72 & $<0.001$ \\
\hline Channel: year & 1 & 0.07 & 6.23 & 0.017 & Channel: year & 1 & 0 & 269.05 & $<0.001$ \\
\hline Channel: season & 2 & 0.03 & 2.57 & 0.095 & Channel: season & 2 & 0 & 15.16 & $<0.001$ \\
\hline Year: season & 2 & 0 & 0.18 & 0.84 & Year: season & 2 & 0.01 & 433.7 & $<0.001$ \\
\hline Channel: year: season & 2 & 0 & 0.17 & 0.842 & Channel: year: season & 2 & 0.01 & 335.27 & $<0.001$ \\
\hline Residuals & 33 & 0.01 & & & Residuals & 33 & 0 & & \\
\hline Total & 44 & & & & Total & 44 & & & \\
\hline Salinity factor & $\mathrm{df}$ & MS & $\mathrm{F}$ & $P$ & Conductivity factor & $\mathrm{df}$ & MS & $\mathrm{F}$ & $P$ \\
\hline Channel & 1 & 0 & 0.38 & 0.54 & Channel & 1 & 0.01 & 5.39 & 0.027 \\
\hline Year & 1 & 0.01 & 6.8 & 0.013 & Year & 1 & 0 & 0.01 & 0.937 \\
\hline Season & 2 & 0.02 & 9.25 & $<0.001$ & Season & 2 & 0.03 & 24.88 & $<0.001$ \\
\hline Channel: year & 1 & 0 & 0.19 & 0.661 & Channel: year & 1 & 0 & 0.27 & 0.599 \\
\hline Channel: season & 2 & 0 & 0.79 & 0.458 & Channel: season & 2 & 0.01 & 5.99 & 0.006 \\
\hline Year: season & 2 & 0.03 & 21.04 & $<0.001$ & Year: season & 2 & 0.01 & 11.15 & $<0.001$ \\
\hline Channel: year: season & 2 & 0 & 0.57 & 0.571 & Channel: year: season & 2 & 0 & 4.31 & 0.021 \\
\hline Residuals & 33 & 0 & & & Residuals & 33 & 0 & & \\
\hline Total & 44 & & & & Total & 44 & & & \\
\hline $\mathrm{pH}$ factor & $\mathrm{df}$ & MS & $\mathrm{F}$ & $P$ & & & & & \\
\hline Channel & 1 & 0 & 1.4 & 0.241 & & & & & \\
\hline Year & 1 & 0.01 & 85.21 & $<0.001$ & & & & & \\
\hline Season & 2 & 0.01 & 161.41 & $<0.001$ & & & & & \\
\hline Channel: year & 1 & 0 & 0.18 & 0.669 & & & & & \\
\hline Channel: season & 2 & 0 & 8.03 & 0.002 & & & & & \\
\hline Year: season & 2 & 0.02 & 248.89 & $<0.001$ & & & & & \\
\hline Channel: year: season & 2 & 0 & 5.28 & 0.01 & & & & & \\
\hline Residuals & 33 & 0 & 0 & & & & & & \\
\hline Total & 44 & 0.07 & & & & & & & \\
\hline
\end{tabular}

According to their residency, ten visiting fishes enter the mangrove seasonally (four species) and occasionally (six species). In contrast, only two species were mangroves residents, which were more abundant (Table 3). 
Table 3. Fish fauna collected from mangrove channels, including their relative abundance (RA), frequency of occurrence (FO), and their category of residency in Terminos Lagoon. OV: occasional visitor, SV: seasonal visitor, R: resident.

\begin{tabular}{|c|c|c|c|c|c|c|}
\hline Family & Scientific name & Common name & Acronym & $\begin{array}{l}\text { RA } \\
(\%)\end{array}$ & $\begin{array}{l}\text { FO } \\
(\%)\end{array}$ & Residency \\
\hline \multicolumn{7}{|l|}{ Order Gobiiformes } \\
\hline Eleotridae & Dormitator maculatus & Fat sleeper & $\mathrm{Dm}$ & 0.1 & 2.2 & OV \\
\hline \multirow[t]{2}{*}{ Gobiidae } & Bathygobius mystacium & Island frillfin & $\mathrm{Bm}$ & 0.03 & 2.2 & OV \\
\hline & Bathygobius soporator & Frillfin goby & Bs & 5.3 & 53.3 & SV \\
\hline \multicolumn{7}{|l|}{ Orden Cichliformes } \\
\hline \multicolumn{6}{|l|}{ Order Cyprinodontiformes } & SV \\
\hline Fundulidae & Fundulus grandissimus & Giant killifish & $\mathrm{Fg}$ & 0.1 & 6.7 & $\mathrm{OV}$ \\
\hline \multirow[t]{3}{*}{ Cyprinodontidae } & Cyprinodon artifrons & Yucatan pupfish & $\mathrm{Ca}$ & 0.1 & 2.2 & $\mathrm{OV}$ \\
\hline & Floridichthys polyommus & Ocellated killifish & $\mathrm{Fp}$ & 0.3 & 8.9 & OV \\
\hline & Garmanella pulchra & Progreso flagfish & Gp & 2.0 & 17.8 & OV \\
\hline \multirow[t]{3}{*}{ Poeciliidae } & Gambusia yucatana & Yucatan gambusia & Gy & 69.3 & 82.2 & $\mathrm{R}$ \\
\hline & Poecilia mexicana & Shortfin molly & Pm & 4.1 & 46.7 & SV \\
\hline & Poecilia velifera & Yucatan molly & $\mathrm{Pv}$ & 12.8 & 62.2 & $\mathrm{R}$ \\
\hline $\begin{array}{l}\text { Order Perciformes } \\
\text { Gerreidae }\end{array}$ & Eucinostomus melanopterus & Flagfin mojarra & $\mathrm{Em}$ & 2.4 & 44.4 & SV \\
\hline
\end{tabular}

Gambusia yucatana was the most numerical abundant species in both years and channels, followed by Frillfin goby Bathygobius soporator at the conserved sites and Yucatan molly Poecilia velifera at the sites under restoration. During both years of sampling, 10 species were recorded. In 2015 Giant killifish Fundulus grandissimus, fat sleeper Dormitator maculatus, and Yucatan pupfish Cyprinodon artifrons were the least abundant species in the sites under restoration, while in 2017, island frillfin Bathygobius mystacium and $F$. grandissimus were the least abundant species. All fishes captured were small specimens, less than 105 $\mathrm{mm}$ standard length (SL), and most were juveniles. Adults only were obtained from small species such as B. mystacium, B. soporator, and C. artifrons (Table 4).

ANOSIM analysis indicated that fish composition varied significantly between channels $(\mathrm{R}=0.16, P=$ $0.01)$. The pairwise test showed that fish communities varied between years and channels, except for the conserved channel in 2015 vs. 2017 (Table 5). Results of SIMPER analysis determined that the greatest dissimilarity occurred between conserved channel and channel under restoration in 2015. The species $B$. soporator, G. yucatana, P. velifera, and Mayaheros urophthalmus explained an important proportion of these dissimilarities. In contrast, the lowest dissimilarity was between the channel under restoration in 2015 and 2017. The species contributing to this differentiation were G. yucatana, P. velifera, Eucinostomus melanopterus, and Garmanella pulchra (Table $6)$.
There were significant differences in richness $\left(\mathrm{F}_{1,44}\right.$ $=7.34, P=0.01)$, Shannon diversity index $\left(\mathrm{F}_{1,44}=\right.$ $14.88, P<0.001)$ and evenness $\left(\mathrm{F}_{1,44}=7.79, P=0.008\right)$ between channels. These values were lower in conserved channel (Table 7). Abundance of resident species was higher in 2017, it varied significantly between years $\left(\mathrm{F}_{1,44}=10.87, P=0.003\right)$.

Conductivity was excluded from GLMM because it was significantly correlated with salinity $(\mathrm{r}=0.77, P<$ 0.05). The GLMM was significant concerning the total species abundance and resident species. The best models indicated that water depth, temperature, and salinity were the most important and significant variables to explain the variation in the abundance of fishes (Table 8).

\section{DISCUSSION}

In this study, after hydrological restoration, the water conditions at the channel sites under restoration showed increased water depth and decreased temperature. We hypothesized that there would be a recovery of ecosystem function, express as an increase of richness and diversity of visiting species. However, we only detected significant changes in fish composition and abundance of some resident and visiting species after reconnecting with Terminos Lagoon and between sites under restoration $v s$. conserved.

The loss and degradation of mangroves by natural disasters produce environmental changes. In 2015, it was found that the canal sites under restoration had high 
Table 4. Abundance (n), standard length (SL), and weight (W) of fishes collected at conserved channel (CC) and channel under restoration (CUR). SL is indicated in millimeters and weight in grams with minimum and maximum values. Dm: Dormitator maculatus, Bm: Bathygobius mystacium, Bs: Bathygobius soporator, Mu: Mayaheros urophthalmus, Fg: Fundulus grandissimus, Ca: Cyprinodon artifrons, Fp: Floridichthys polyommus, Gp: Garmanella pulchra, Gy: Gambusia yucatana, Pm: Poecilia mexicana, Pv: Poecilia velifera, Em: Eucinostomus melanopterus.

\begin{tabular}{|c|c|c|c|c|c|c|c|c|c|c|c|}
\hline $\mathrm{CC}$ & 2015 & $\mathrm{Dm}$ & Bs & $\mathrm{Mu}$ & $\mathrm{Fg}$ & $\mathrm{Ca}$ & Gp & Gy & $\mathrm{Pm}$ & $\mathrm{Pv}$ & $\mathrm{Em}$ \\
\hline \multirow[t]{3}{*}{ Nortes } & $\mathrm{n}$ & & 13 & & & & & 51 & 17 & 5 & 6 \\
\hline & SL & & $19.1-58.8$ & & & & & $16.1-29.4$ & $25.5-42.3$ & $27.7-37.3$ & $22.8-59.3$ \\
\hline & W & & $0.1-4.9$ & & & & & $0.1-0.5$ & $0.4-2.0$ & $0.5-1.4$ & $0.3-4.6$ \\
\hline \multirow[t]{3}{*}{ Dry } & $\mathrm{n}$ & & 11 & & & & & 10 & & & 1 \\
\hline & SL & & $34.1-51.4$ & & & & & $15.7-29.4$ & & & 31.2 \\
\hline & W & & $0.8-2.6$ & & & & & $0.1-0.6$ & & & 0.6 \\
\hline \multirow[t]{3}{*}{ Rainy } & $\mathrm{n}$ & & 20 & 1 & & & & 2 & & & 1 \\
\hline & SL & & $31.3-53.1$ & 11.9 & & & & $16.6-26.7$ & & & 25.2 \\
\hline & W & & $0.6-3.7$ & 0.1 & & & & $0.1-0.4$ & & & 0.3 \\
\hline CUR & 2015 & Dm & Bs & $\mathrm{Mu}$ & $\mathrm{Fg}$ & $\mathrm{Ca}$ & Gp & Gy & $\mathrm{Pm}$ & $\mathrm{Pv}$ & Em \\
\hline \multirow[t]{3}{*}{ Nortes } & $\mathrm{n}$ & & & 1 & & 2 & 6 & 131 & 1 & 73 & \\
\hline & SL & & & 30.9 & & $30.6-31.4$ & $14.4-22.6$ & $13.3-34.4$ & 28.4 & $20.6-51.9$ & \\
\hline & W & & & 0.2 & & $1.0-1.1$ & $0.1-0.4$ & $0.04-0.9$ & 1.4 & $0.2-4.4$ & \\
\hline \multirow{3}{*}{ Dry } & $\mathrm{n}$ & & & 14 & & & 17 & 40 & 7 & 40 & 2 \\
\hline & SL & & & $14.3-22.6$ & & & $17.2-27.4$ & $12.4-33.6$ & $17.2-46.6$ & $22.0-50.7$ & $43.2-48.1$ \\
\hline & $\mathrm{W}$ & & & $0.1-0.4$ & & & $0.1-0.7$ & $0.1-0.9$ & $0.1-2.7$ & $0.3-4.0$ & $1.62-2.52$ \\
\hline \multirow[t]{3}{*}{ Rainy } & $\mathrm{n}$ & 2 & & 8 & 1 & & & 18 & & 39 & 26 \\
\hline & SL & $37.2-37.8$ & & $10.4-59.3$ & 39.5 & & & $10.5-22.9$ & & $13.7-38.6$ & $13.2-35.5$ \\
\hline & W & $0.8-1.0$ & & $0.04-6.7$ & 1.1 & & & $0.02-0.2$ & & $0.1-1.8$ & $0.2-1.0$ \\
\hline $\mathrm{CC}$ & 2017 & $\mathrm{Bm}$ & Bs & $\mathrm{Mu}$ & $\mathrm{Fg}$ & $\mathrm{Fp}$ & Gp & Gy & $\mathrm{Pm}$ & $\mathrm{Pv}$ & Em \\
\hline \multirow[t]{3}{*}{ Nortes } & $\mathrm{n}$ & & 23 & & & 1 & 34 & 100 & 26 & 14 & \\
\hline & SL & & $26.3-65.8$ & & & 52.0 & $12.9-25.9$ & $15.0-35.5$ & $20.5-46.5$ & $35.3-49.4$ & \\
\hline & W & & $0.3-6.6$ & & & 4.4 & $0.1-0.5$ & $0.1-0.8$ & $0.2-2.3$ & $1.0-2.9$ & \\
\hline \multirow[t]{3}{*}{ Dry } & $\mathrm{n}$ & & 57 & & & & & 53 & & 9 & 1 \\
\hline & SL & & $25.3-63.5$ & & & & & $14.6-35.3$ & & 29.9-53.7 & 52.9 \\
\hline & W & & $0.3-5.2$ & & & & & $0.04-0.8$ & & $0.7-3.8$ & 3.4 \\
\hline \multirow[t]{3}{*}{ Rainy } & $\mathrm{n}$ & & 18 & 2 & & & & 1092 & 15 & 2 & \\
\hline & SL & & $12.8-56.5$ & $13.3-48.3$ & & & & $7.1-37.5$ & $13.7-32.8$ & $33.0-38.4$ & \\
\hline & W & & $0.03-5.2$ & $0.1-3.8$ & & & & $0.01-1.0$ & $0.1-0.7$ & $0.9-1.3$ & \\
\hline CUR & 2017 & $\mathrm{Bm}$ & Bs & $\mathrm{Mu}$ & $\mathrm{Fg}$ & $\mathrm{Fp}$ & Gp & Gy & $\mathrm{Pm}$ & $\mathrm{Pv}$ & $\mathrm{Em}$ \\
\hline \multirow[t]{3}{*}{ Nortes } & $\mathrm{n}$ & 1 & 2 & 24 & & 1 & & 133 & 10 & 50 & 6 \\
\hline & SL & 43.4 & $27.7-39.9$ & $27.1-61.6$ & & 59.0 & & $13.3-39.7$ & $31.0-52.0$ & $15.7-55.0$ & $41.6-59.7$ \\
\hline & W & 1.6 & $0.4-1.2$ & $0.7-8.9$ & & 6.2 & & $0.03-1.2$ & $0.6-3.4$ & $0.1-4.2$ & $1.8-5.2$ \\
\hline \multirow[t]{3}{*}{ Dry } & $\mathrm{n}$ & & 5 & 12 & 2 & & & 70 & 22 & 102 & 20 \\
\hline & SL & & $47.3-68.3$ & $16.8-77.0$ & $82.7-105.4$ & & & $8.3-34.6$ & $19.4-55.1$ & $12.7-61.9$ & $31.6-60.0$ \\
\hline & W & & $1.9-7.4$ & $0.2-15.6$ & $10.9-19.3$ & & & $0.01-0.9$ & $0.2-4.0$ & $0.1-5.5$ & $0.7-5.2$ \\
\hline \multirow{3}{*}{ Rainy } & $\mathrm{n}$ & & 1 & 35 & & 6 & & 257 & 19 & 27 & 6 \\
\hline & SL & & 76.5 & $13.3-48.3$ & & $26.6-37.8$ & & $8.1-28.9$ & $15.8-41.0$ & $25.3-54.9$ & $24.4-46.9$ \\
\hline & W & & 8.7 & $0.1-3.8$ & & $0.6-1.7$ & & $0.01-0.57$ & $0.1-1.7$ & $0.4-5.8$ & $0.4-2.7$ \\
\hline
\end{tabular}

temperatures and less depth compared to the conserved sites. These conditions are like other degraded mangroves, which exhibit greater sedimentation (Adite et al. 2013), greater heating and evaporation of the water column than deep sites, leading to an increase in temperature (Kennish 2017). After hydrological restoration, there was an increase in water depth, although it was less compared to conserved sites, and the environmental differences between the channels remained.

Salinity varied seasonally, as in natural mangrove ecosystems (Faunce \& Serafy 2006) but did not decrease after the restoration process (Adite et al. 2013). Instead, there was an increase in the average values of salinity and $\mathrm{pH}$ of both channels in 2017. Salinity is an important factor in the distribution and 
abundance of fish in a mangrove (Nagelkerken et al. 2008), given the different osmoregulatory capacities of different fish species and the salinity impact on other parameters such as pH (Smyth \& Elliot 2016). Terminos Lagoon displays seasonal and spatial variations of salinity (Herrera-Silveira et al. 2019). However, in recent years, this ecosystem recorded an increase in salinity, with subsequent changes in fish diversity and composition of species (Ramos-Miranda et al. 2005, 2015). Also, the variations of salinity are associated with climate change (Fichez et al. 2017).
Table 5. Results of post-hoc test of ANOSIM for the fish community between the conserved channel (CC) and channel under restoration (CUR) in 2015 and 2017. R: statistics R, $P$ : $P$-value.

\begin{tabular}{lll}
\hline Pairwise & $\mathrm{R}$ & $P$ \\
\hline CC 2015 vs. CC 2017 & 0.13 & 0.1 \\
CC 2015 vs. CUR 2015 & 0.63 & 0.001 \\
CUR 2015 vs. CUR 2017 & 0.16 & 0.01 \\
CC 2017 vs. CUR 2017 & 0.41 & 0.001 \\
\hline
\end{tabular}

Table 6. SIMPER analysis showed the five species that contributed most to the dissimilarity of fish communities between channels and years. CC: conserved channel, CUR: channel under restoration.

\begin{tabular}{lccc}
\hline Species & Average dissimilarity & Contribution \% & Cumulative \% \\
\hline CC 2015 vs. CUR 2015 (average dissimilarity: 81.07) & & \\
\hline Bathygobius soporator & 18.23 & 22.49 & 22.49 \\
Gambusia yucatana & 13.86 & 17.10 & 39.59 \\
Poecilia velifera & 13.66 & 16.86 & 56.44 \\
Mayaheros urophthalmus & 10.18 & 12.55 & 68.99 \\
\hline CC 2017 vs. CUR 2017 (average dissimilarity: 61.56) & & \\
\hline Gambusia yucatana & 14.43 & 23.43 & 23.43 \\
Poecilia velifera & 10.91 & 17.72 & 41.15 \\
Bathygobius soporator & 10.68 & 17.34 & 58.49 \\
Mayaheros urophthalmus & 9.28 & 15.08 & 73.57 \\
\hline CUR 2015 vs. CUR 2017 (average dissimilarity: 54.89) & & \\
\hline Gambusia yucatana & 11.93 & 21.74 & 21.74 \\
Poecilia velifera & 10.95 & 19.95 & 41.69 \\
Eucinostomus melanopterus & 6.58 & 11.99 & 53.68 \\
Garmanella pulchra & 6.56 & 11.94 & 65.63 \\
\hline
\end{tabular}

Ecological indicators of restoration were the changes in composition and abundance of some species. In 2015, the gobiid $B$. soporator was the main visiting species that supported the differences between channels. This species was absent on the channel under restoration, and it was the most abundant visiting species in the conserved channel. This small benthic species (Carpenter 2002) is common euryhaline fish found in estuarine environments and mangrove areas (Arceo-Carranza \& Vega-Cendejas 2009, Soares et al. 2016). In 2017, this gobiid was caught in the sites under restoration; their presence resulted from the reconnection with Terminos Lagoon because this species enters estuarine areas with tidal movements (Ellis \& Bell 2008).

After restoration, there was an increase in the abundance of flagfish mojarra E. melanopterus. This is a marine and euryhaline species that cyclically enters estuaries, in its larval and juvenile state to feed and grow (García-Hernández et al. 2009). It is a dominant species in other restored mangroves (Peters et al. 2015).
In Terminos Lagoon, this species inhabits mangrove areas, seagrasses and macroalgae (Aguirre-León et al. 1982), and fluvial-lagoon systems (Ramos-Miranda et al. 2006). Its increase in the channel under restoration is an indicator of the influx of tidal water.

After two years, the sites under restoration showed an increase in the abundance of resident species, $G$. yucatana and $P$. velifera. Although both are freshwater species, they can tolerate euryhaline conditions (30-40 ups) due to their broad osmoregulatory capacity (Carter 1981, Neves et al. 2019). These species typically constitute the resident fish in estuarine systems (ArceoCarranza \& Vega-Cendejas 2009) and petenes (TorresCastro et al. 2009). Both are also abundant in mangroves under restoration, with $G$. yucatana showing a greater abundance in sites with recent restoration (Arceo-Carranza et al. 2016).

Richness, diversity, and uniformity were not expected to be significantly different between channels and higher at restoration sites. Because conserved sites typically have a high richness and diversity of fishes 
Table 7. Mean values of richness, Shannon $(\mathrm{H})$, and Pielou (J) indices of the fish community in channels of Terminos Lagoon. Standards deviation are included in parenthesis.

\begin{tabular}{llllll}
\hline Year & Channel & Season & Richness & Diversity $(\mathrm{H})$ & Evenness (J) \\
\hline 2015 & Conserved & Nortes & $5.0(0)$ & $1.1(0.2)$ & $0.7(0.1)$ \\
& & Dry & $2.0(1.4)$ & $0.4(0.6)$ & $0.4(0.6)$ \\
& & Rainy & $2.3(1.5)$ & $0.4(0.4)$ & $0.3(0.3)$ \\
& \multirow{4}{*}{ Under restoration } & Nortes & $4.5(2.1)$ & $0.9(0.2)$ & $0.7(0.4)$ \\
& & Dry & $3.8(2.0)$ & $1.0(0.4)$ & $0.8(0.1)$ \\
2017 & \multirow{4}{*}{ Conserved } & Rainy & $4.3(1.0)$ & $1.1(0.3)$ & $0.8(0.1)$ \\
& & Nortes & $3.0(2.2)$ & $0.7(0.6)$ & $0.6(0.4)$ \\
& & Dry & $2.8(1.0)$ & $0.7(0.2)$ & $0.7(0.1)$ \\
& \multirow{4}{*}{ Under restoration } & Rainy & $3.4(0.9)$ & $0.2(0.2)$ & $0.3(0.3)$ \\
& & Nortes & $5.0(1.6)$ & $1.0(0.4)$ & $0.7(0.2)$ \\
& Dry & $5.0(2.3)$ & $1.1(0.6)$ & $0.6(0.3)$ \\
& Rainy & $4.6(1.7)$ & $1.0(0.4)$ & $0.7(0.2)$ \\
\hline
\end{tabular}

Table 8. The generalized mixed linear model (MMGL) analyzes environmental variables' effect on the abundance of all species and resident species. ${ }^{* * *} P<0.001$. AIC: Akaike Information Criterion, BIC: Bayesian Information Criterion.

\begin{tabular}{lccclll}
\hline $\begin{array}{l}\text { Abundance all } \\
\text { species }\end{array}$ & $\begin{array}{c}\text { AIC }=2346.1 \\
\text { Estimate }\end{array}$ & $\begin{array}{c}\mathrm{BIC}=2355.2 \\
\text { Standard error }\end{array}$ & $\mathrm{z}$ value & $P(>|\mathrm{z}|)$ & \\
\hline (Intercept) & 10.255 & 0.528 & 19.427 & $<2 \mathrm{e}-16$ & $* * *$ \\
Water depth & 0.759 & 0.154 & 4.939 & $7.84 \mathrm{E}-07$ & $* * *$ \\
Temperature & -0.065 & 0.006 & -11.253 & $<2 \mathrm{e}-16$ & $* * *$ \\
Salinity & -0.153 & 0.005 & -29.739 & $<2 \mathrm{e}-16$ & $* * *$ \\
\hline \multirow{2}{*}{ Resident species } & AIC $=2346.1$ & $\mathrm{BIC}=2355.2$ & \multirow{2}{*}{$\mathrm{z}$ value } & $P(>|\mathrm{z}|)$ & \\
& Estimate & Standard error & & & \\
\hline (Intercept) & 11.652 & 0.713 & 16.334 & $<2 \mathrm{e}-16$ & $* * *$ \\
Water depth & 1.089 & 0.179 & 6.088 & $1.14 \mathrm{E}-09$ & $* * *$ \\
Temperature & -0.083 & 0.007 & -12.428 & $<2 \mathrm{e}-16$ & $* * *$ \\
Salinity & -0.199 & 0.006 & -32.365 & $<2 \mathrm{e}-16$ & $* * *$ \\
\hline
\end{tabular}

(Bosire et al. 2008, Valentine-Rose \& Layman 2011). Although different sampling techniques were applied in both channels and the most effective ones were chosen, it is necessary to include others to improve conserved sites' diversity. For example, snorkeling allows recording large-sized fish that enter the mangrove to feed like barracudas or snappers (Valentine-Rose \& Layman 2011, Peters et al. 2015). It is also important to extend the sampling hours to record the dynamics of the mangroves (Schaberg et al. 2019).

According to GLMM, water depth, temperature, and salinity significantly affect the abundance of residents and overall species. A greater abundance is expected as water depth increases because, after the hydrological restoration, mangroves recuperate their natural hydrological flow and tidal influence (ZaldívarJiménez et al. 2017, Pérez-Ceballos et al. 2020). Natural and long-term restored mangroves have greater water depth and lower temperature (Adite et al. 2013), as well tides that favor the entrance of visiting fishes to the restored mangrove (Salmo et al. 2018). However, the response of the ichthyofauna to the restoration process is varied, and it depends on the species analyzed (Vose \& Bell 1994, Trexler \& Gross 2009). In this work, we expected that the response of resident species is reliable because these livebearers have similar tolerances, osmoregulatory capacities (Carter 1981, Neves et al. 2019), feeding strategies, and life cycles (Miller 2009).

We detected changes in fish composition and abundance related to hydrological reconnection with the Terminos Lagoon in the short term. It is expected that the characteristics and structure of the restored ecosystem will be similar in the medium-to-long term (Moreno-Mateos et al. 2020). In this study, the evaluation was carried out in two years, and perhaps it was little to show changes in the fish community. The recovery of function of the mangrove ecosystem will take time; major changes in the structure of fish communities exhibit mangroves with a longer resto- 
ration period (Arceo-Carranza et al. 2016, Schaberg et al. 2019) because mangrove restoration involves a natural regeneration process (Echeverría-Ávila et al. 2019, Pérez-Ceballos et al. 2020). As mangrove structure and function are restored, it is expected that more habitats and resources will be made available to fish, like invertebrates, and larger and commercially important species such as the snooks (Family Centropomidae) or the snappers (Family Lutjanidae) - will enter the site under restoration (Schaberg et al. 2019).

This analysis of fish fauna at a conserved channel $v s$. a channel under restoration highlighted changes in the composition and abundance of visiting marine species and resident species. These changes indicate the reconnection of mangroves through natural tidal hydrology, especially visiting marine fishes: $B$. soporator and E. melanopterus. Although we detected small changes in the fish community, we considered that fish are useful biological indicators to monitor the effectiveness of restoration. Fishes can indicate changes in productivity of mangroves (Valentine-Rose \& Layman 2011, Arceo-Carranza et al. 2016) and the fauna recovery (Trexler \& Gross 2009). Further hydrological restoration work is necessary at selected sites within this region to restore the richness, abundance, diversity, and function of these ecosystems to their natural condition. Recovery must be paired with systematic monitoring of the mangroves' environmental characteristics and aspects of the fish fauna. Assessments of fish fauna should consider seasonal and dial variation in the area and include the trophic guilds. Through trophic ecology, it will be possible to evaluate restored mangrove's health and functioning to determine the link between mangrove detritus and food chains, the available resources for consumers, and understand the flow of nutrients and the trophic dynamics in the restored ecosystem.

\section{ACKNOWLEDGMENTS}

MSB and HERR thank CONACyT for the scholarships awarded. We thank the anonymous reviewers who provided helpful comments that improved the manuscript. HERR's master's thesis generated the data. The work was financed by the project "Biodiversidad acuática en la zona costera del sureste de México. Red temática de colaboración PRODEP”.

\section{REFERENCES}

Adite, A., Imorou-Toko, I. \& Gbankoto, A. 2013. Fish assemblages in the degraded mangrove ecosystems of the coastal zone, Benin, West Africa: implications for ecosystem restoration and resources conservation.
Journal of Environmental Protection, 4: 1461-1475. doi: 10.4236/jep.2013.412168

Aguirre-León, A., Yáñez-Arancibia, A. \& AmezcuaLinares, F. 1982. Taxonomía, diversidad, distribución y abundancia de las mojarras de la Laguna de Términos, Campeche (Pisces:Gerridae). Anales del Instituto de Ciencias del Mar y Limnología, 9: 213250.

Amador-del Ángel, L.E., Guevara-Carrió, E. del C., Brito, R. \& Wakida-Kusunoki, A.T. 2015. Length-weight relationships of fish species associated with the mangrove forest in the southwestern Terminos Lagoon, Campeche (Mexico). Journal of Applied Ichthyology, 31: 228-230. doi: 10.1111/jai.12490

Anderson, M.J. 2001. A new method for non-parametric multivariate analysis of variance. Austral Ecology, 26: 32-46. doi: 10.1080/13645700903062353

Arceo-Carranza, D., Gamboa, E., Teutli-Hernández, C., Badillo-Alemán, M. \& Herrera-Silveira, J.A. 2016. Los peces como indicador de restauración de áreas de manglar en la costa norte de Yucatán. Revista Mexicana de Biodiversidad, 87: 489-496. doi: 10.1016/ j.rmb.2016.03.001

Arceo-Carranza, D. \& Vega-Cendejas, M.E. 2009. Spatial and temporal characterization of fish assemblages in a tropical coastal system influenced by freshwater inputs: northwestern Yucatan peninsula. Revista de Biología Tropical, 57: 89-103. doi: 10.15517/rbt.v57i1-2.11293

Bates, D., Maenchler, M., Bolker, B. \& Walker, S. 2015. Fitting linear mixed-effects models using lme4. Journal of Statistical Sofware, 67: 1-48.

Blaber, S.J.M. 2007. Mangroves and fishes: issues of diversity, dependence, and dogma. Bulletin of Marine Science, 80: 457-472.

Bosire, J.O., Dahdouh-Guebas, F., Walton, M., Crona, B.I., Lewis III, R.R., Field, C., et al. 2008. Functionality of restored mangroves: a review. Aquatic Botany, 89: 251-259. doi: 10.1016/j.aquabot.2008.03.010

Canales-Delgadillo, J.C., Pérez-Ceballos, R., ZaldívarJiménez, M.A., Merino-Ibarra, M., Cardoza, G. \& Cardoso-Mohedano, J.G. 2019. The effect of mangrove restoration on avian assemblages of a coastal lagoon in southern Mexico. PeerJ, 7: e7493. doi: $10.7717 /$ peerj.7493

Carpenter, K.E. 2002. The living marine resources of the Western Central Atlantic. Volume 2: bony fishes part 1 (Acipenseridae to Grammatidae). FAO Species Identification Guide for Fishery Purposes and American Society of Ichthyologists and Herpetologists Special Publication No. 5, Rome. 
Carter, H.J. 1981. Aspects of the physiological ecology of species of Gambusia from Belize, Central America. Copeia, 1981: 694-700. doi: 10.2307/1444576

Castro-Aguirre, J.L., Espinosa-Pérez, H. \& SchmitterSoto, J.J. 1999. Ictiofauna estuarino-lagunar y vicaria de México. Limusa, Ciudad de México.

Clarke, K.R. 1993. Non-parametric multivariate analyses of changes in community structure. Austral Ecology, 18: 117-143. doi: 10.1111/j.1442-9993.1993.tb0043 8. $\mathrm{X}$

Clarke, K.R. \& Warwick, R.M. 1998. A taxonomic distinctness index and its statistical properties. Journal of Applied Ecology, 35: 523-531.

Comisión Nacional para el Conocimiento y Uso de la Biodiversidad (CONABIO) - Secretaría de Medio Ambiente y Recursos Naturales de Campeche (SEMARNATCAM). 2016. Estrategia para la conservación y el uso sustentable de la biodiversidad en el estado de Campeche. CONABIO, Ciudad de México.

Echeverría-Ávila, S., Pérez-Ceballos, R., ZaldívarJiménez, A., Canales-Delgadillo, J., Brito-Pérez, R., Merino-Ibarra, M. \& Vovides, A. 2019. Regeneración natural de sitios de manglar degradado en respuesta a la restauración hidrológica. Madera y Bosques, 25: e2511754. doi: 10.21829/myb.2019.2511754

Ellis, W.L. \& Bell, S.S. 2008. Tidal influence on a fringing mangrove intertidal fish community as observed by in situ video recording: implications for studies of tidally migrating nekton. Marine Ecology Progress Series, 370: 207-219. doi: 10.3354/meps07567

Ellison, A.M. 2000. Mangrove restoration: Do we know enough? Restoration Ecology, 8: 219-229. doi: 10.1046/j.1526-100X.2000.80033.x

Escudero, M., Silva, R. \& Mendoza, E. 2014. Beach erosion driven by natural and human activity at Isla del Carmen Barrier Island, Mexico. Journal of Coastal Research, 71: 62-74. doi: 10.2112/si71-008.1

Faunce, C.H. \& Serafy, J.E. 2006. Mangroves as fish habitat: 50 years of field studies. Marine Ecology Progress Series, 318: 1-18. doi: 10.3354/meps318001

Fichez, R., Archundia, D., Grenz, C., Douillet, P., Gutiérrez Mendieta, F., Origel Moreno, M., et al. 2017. Global climate change and local watershed management as potential drivers of salinity variation in a tropical coastal lagoon (Laguna de Terminos, Mexico). Aquatic Sciences, 79: 219-230. doi: 10.1007/ s00027-016-0492-1

García-Hernández, V., Ordóñez-López, U., HernándezVásquez, T. \& Álvarez-Cadena, J.N. 2009. Fish larvae and juveniles checklist (Pisces) from the northern Yucatan Peninsula, Mexico, with 39 new records for the region. Revista Mexicana de Biodiversidad, 80: 85-94.
Gilman, E.L., Ellison, J., Duke, N.C. \& Field, C. 2008. Threats to mangroves from climate change and adaptation options: a review. Aquatic Botany, 89: 237250. doi: 10.1016/j.aquabot.2007.12.009

Herrera-Silveira, J.A., Lara-Domínguez, A.L., Day, J.W., Yáñez-Arancibia, A., Ojeda, S.M., Hernández, C.T. \& Kemp, G.P. 2019. Ecosystem functioning and sustainable management in coastal systems with high freshwater input in the southern Gulf of Mexico and Yucatan Peninsula. In: Wolanski, E., Day, J.W., Elliot M. \& Ramachandran, R. (Eds.). Coasts and estuaries: the future. Elsevier, Oxford, pp. 377-397.

Himes-Cornell, A., Grose, S.O. \& Pendleton, L. 2018. Mangrove ecosystem service values and methodological approaches to valuation: where do we stand? Frontiers in Marine Science, 5: 376. doi: 10.3389/ fmars.2018.00376

Kennish, M.J. 2017. Ecology of estuaries. Physical and chemical aspects. CRC Press, Boca Raton.

Lee, S.Y., Primavera, J.H., Dahdouh-Guebas, F., McKee, K., Bosire, J.O., Cannicci, S., et al. 2014. Ecological role and services of tropical mangrove ecosystems: a reassessment. Global Ecology and Biogeography, 23: 726-743. doi: 10.1111/geb.12155

Lewis III, R.R. \& Gilmore, R.G. 2007. Important considerations to achieve successful mangrove forest restoration with optimum fish habitat. Bulletin of Marine Science, 80: 823-837.

López-Portillo, J., Lewis III, R.R., Saenger, P., Rovai, A., Koedam, N., Dahdouh-Guebas, F., et al. 2017. Mangrove forest restoration and rehabilitation. In: Rivera-Monroy, V.H., Lee, S.Y., Kristensen, E. \& Twiley R.R. (Eds.). Mangrove ecosystems: a global biogeographic perspective: structure, function, and services. Springer International Publishing, Cham, pp. 301-345.

Miller, R.R. 2009. Peces dulceacuícolas de México. CONABIO, SIMAC, ECOSUR, DFC, Ciudad de México.

Morales-Serna, F.N., Rodríguez-Santiago, M.A., Gelabert, R. \& Flores-Morales, L.M. 2019. Parasites of fish Poecilia velifera and their potential as bioindicators of wetland restoration progress. Helgoland Marine Research, 73: 1. doi: 10.1186/s10152-019-0522-1

Moreno-Mateos, D., Alberdi, A., Morriën, E., Van der Putten, W.H., Rodríguez-Uña, A. \& Montoya, D. 2020. The long-term restoration of ecosystem complexity. Nature Ecology and Evolution, 4: 676-685. doi: 10.1038/s41559-020-1154-1

Moreno-Mateos, D., Power, M.E., Comín, F.A. \& Yockteng, R. 2012. Structural and functional loss in restored wetland ecosystems. Plos Biology, 10: e1001247. doi: 10.1371/journal.pbio. 1001247 
Nagelkerken, I., Blaber, S.J.M., Bouillon, S., Green, P., Haywood, M., Kirton, L.G., et al. 2008. The habitat function of mangroves for terrestrial and marine fauna: a review. Aquatic Botany, 89: 155-185. doi: 10.1016/ j.aquabot.2007.12.007

Oksanen, J., Blanchet, F.G., Friendly, M., Kindt, R., Legendre, P., McGlinn, D., et al. 2019. vegan: community ecology package. R package version $2.5-$ 6. R Foundation for Statistical Computing, Vienna.

Neves, L. do C., Cipriano, F., Lorenzini, J.P.S., Cipriano, K.S. de L., Gonçalves Junior, L.P., Nakayama, C.L., et al. 2019. Effects of salinity on sexual maturity and reproduction of Poecilia velifera. Aquaculture Research, 50: 2932-2937. doi: 10.1111/are.14247

Padilla-Serrato, J., López-Martínez, J., RodríguezRomero, J., Acevedo-Cervantes, A., Galván-Magaña, F. \& Lluch-Cota, D. 2017. Changes in fish community structures in a coastal lagoon in the Gulf of California, México. Revista de Biología Marina y Oceanografía, 52: 567-579. doi: 10.4067/s0718-19572017000300 013

Pérez-Ceballos, R., Zaldívar-Jiménez, A., CanalesDelgadillo, J., López-Adame, H., López-Portillo, J. \& Merino-Ibarra, M. 2020. Determining hydrological flow paths to enhance restoration in impaired mangrove wetlands. Plos One, 15: e0227665. doi: 10.1371/ journal.pone.0227665

Peters, J.R., Yeager, L.A. \& Layman, C.A. 2015. Comparison of fish assemblages in restored and natural mangrove habitats along an urban shoreline. Bulletin of Marine Science, 91: 125-139. doi: 10.5343/ bms.2014.1063

R Core Team. 2000. R: a language and environment for statistical computing. R Foundation for Statistical Computing, Vienna.

Ramos-Miranda, J., Flores-Hernández, D., Ayala-Pérez, L.A., Rendón-von Osten, J., Villalobos-Zapata, G. \& Sosa-López, A. 2006. Atlas hidrológico e ictiológico de la Laguna de Términos. Universidad Autónoma de Campeche. Campeche.

Ramos-Miranda, J., Quiniou, L., Flores-Hernández, D., Do-Chi, T., Ayala-Pérez, L.A. \& Sosa-López, A. 2005. Spatial and temporal changes in the nekton of the Terminos Lagoon, Campeche, Mexico. Journal of Fish Biology, 66: 513-530. doi: 10.1111/j.00221112.2005.00619.x

Ramos-Miranda, J., Flores, H.D., Sosa, L.A., Ayala, P.L.A., Villeger, S., Pérez, S.M.I., et al. 2015. La comunidad del necton en la laguna de Términos: modificación del hábitat vs. cambios en la comunidad. In: Ramos, M.J. \& Villalobos-Zapata, G.J. (Eds.). Aspectos socioambientales de la región de la Laguna de Términos, Campeche. Universidad Autónoma de Campeche, Campeche, pp. 181-198.
Romañach, S.S., DeAngelis, D.L., Koh, H.L., Li, Y., Teh, S.Y., Raja-Barizan, R.S. \& Zhai, L. 2018. Conservation and restoration of mangroves: global status, perspectives, and prognosis. Ocean and Coastal Management, 154: 72-82. doi: 10.1016/j.ocecoaman. 2018.01.009

Salmo III, S.G., Tibbetts, I.R. \& Duke, N.C. 2018. Nekton communities as indicators of habitat functionality in Philippine mangrove plantations. Marine and Freshwater Research, 69: 477-485. doi: 10.1071/MF17116

Schaberg, S.J., Patterson, J.T., Hill, J.E., Guindon, K.Y. \& Tuckett, Q.M. 2019. Fish community composition and diversity at restored estuarine habitats in Tampa Bay, Florida, United States. Restoration Ecology, 27: 5462. doi: org/10.1111/rec. 12712

Sepúlveda-Lozada, A., Saint-Paul, U., MendozaCarranza, M., Wolff, M. \& Yáñez-Arancibia, A. 2017. Flood pulse induced changes in isotopic niche and resource utilization of consumers in a Mexican floodplain system. Aquatic Sciences, 79: 597-616. doi: 10.1007/s00027-017-0520-9

Smyth, K. \& Elliot, M. 2016. Effects of changing salinity on the ecology of the marine environment. In: Solan, M. \& Whiteley, N. (Eds.). Stressors in the marine environment: physiological and ecological responses; societal implications. Oxford University Press, Oxford, pp. 161-174.

Soares, B.E., Lobato, C.M.C., Freitas, D.T.H., OliveiraRaiol, R.D. \& Montag, L.F.A. 2016. Sex differences on the feeding of the gobiid fish Bathygobius soporator in tide pools of Maiandeua Island, Pará, Brazil. Iheringia - Serie Zoologia, 106: 1-4. doi: 10.1590/1678-4766e2016008

Soto-Galera, E., Piera, J. \& López, P. 2010. Spatial and temporal land cover changes in Terminos Lagoon Reserve, Mexico. Revista de Biología Tropical, 58: 565-575.

Torres-Castro, I.L., Vega-Cendejas, M.E., SchmitterSoto, J.J., Palacio-Aponte, G. \& Rodiles-Hernández, R. 2009. Ictiofauna de sistemas cárstico-palustres con impacto antrópico: los petenes de Campeche, México. Revista de Biología Tropical, 57: 141-157.

Trexler, J.C. \& Goss, C.W. 2009. Aquatic fauna as indicators for Everglades restoration: applying dynamic targets in assessments. Ecological Indicators, 9: 108-119. doi: 10.1016/j.ecolind.2008.11.001

Turner, R.E. \& Lewis III, R.R. 1997. Hydrologic restoration of coastal wetlands. Wetlands Ecology and Management, 4: 65-72. doi: 10.1007/bf01876229

Valentine-Rose, L. \& Layman, C.A. 2011. Response of fish assemblage structure and function following restoration of two small Bahamian tidal creeks. Restoration Ecology, 19: 205-215. doi: 10.1111/j.1526100X.2009.00553.x 
Vose, F.E. \& Bell, S.S. 1994. Resident fishes and macrobenthos in mangrove-rimmed habitats: evaluation of habitat restoration by hydrologic modification. Estuaries, 17: 585-596. doi: 10.2307/1352406

Whitfield, A.K. 2017. The role of seagrass meadows, mangrove forests, salt marshes and reed beds as nursery areas and food sources for fishes in estuaries. Reviews in Fish Biology and Fisheries, 27: 75-110. doi: 10.1007/s11160-016-9454-X

Wortley, L., Hero, J.M. \& Howes, M. 2013. Evaluating ecological restoration success: a review of the literature. Restoration Ecology, 21: 537-543. doi: 10.1111/rec. 12028

Yáñez-Arancibia, A., Lara-Domínguez, A.L. \& Day, J.W.J. 1993. Interactions between mangrove and seagrass habitats mediated by estuarine nekton assemblages: coupling of primary and secondary production. Hydrobiologia, 264: 1-12. doi: 10.1007/ BF00014659

Received: 9 September 2020; Accepted: 30 April 2021
Zaldívar-Jiménez, A., Ladrón de Guevara-Porras, P., Pérez-Ceballos, R., Díaz-Mondragón, S. \& RosadoSolórzano, R. 2017. US-Mexico joint Gulf of Mexico large marine ecosystem based assessment and management: experience in community involvement and mangrove wetland restoration in Términos lagoon, Mexico. Environmental Development, 22: 206-213. doi: 10.1016/j.envdev.2017.02.007

Zaldívar-Jiménez, A., Herrera-Silveira, J.A., TeutliHernández, C., Comín, F.A., Andrade, J.L., Molina, C.C. \& Pérez-Ceballos, R. 2010. Conceptual framework for mangrove restoration in the Yucatán Peninsula. Ecological Restoration, 28: 333-342. doi: 10.3368/er.28.3.333

Zhao, Q., Bai, J., Huang, L., Gu, B., Lu, Q. \& Gao, Z. 2016. A review of methodologies and success indicators for coastal wetland restoration. Ecological Indicators, 60: 442-452. doi: 10.1016/j.ecolind.2015. 07.003 